\title{
THE RENAL EXCRETION OF ENDOGENOUS CREATININE IN MAN. COMPARISON WITH EXOGENOUS CREATININE AND INULIN
}

\author{
By BENJAMIN F. MILLER AND ALEXANDER W. WINKLER \\ (From the Hospital of the Rockefeller Institute for Medical Research, New York and the \\ Department of Internal Medicine of Yale University, New Haven)
}

(Received for publication August 6, 1937)

The study of the renal excretion of creatinine has been concerned hitherto largely with exogenous creatinine because of difficulties in the determination of endogenous plasma creatinine. Behre and Benedict (1) and others $(2,3)$ have denied the presence of any appreciable amount of creatinine in normal plasma. On the other hand several authors have reached the opposite conclusion $(4,5,6)$. To avoid this controversy investigators of the renal excretion of creatinine have administered creatinine orally or intravenously to raise the concentration in plasma to levels much above that of the " endogenous chromogenic substance." 1 In this way it is possible to obtain values for exogenous creatinine which are not appreciably influenced by the color development of the endogenous Jaffe-reactive material. This technique was employed by Rehberg (7) when he suggested the creatinine clearance as a measure of the true glomerular filtrate in the human kidney. He gives by mouth 5 grams of creatinine one hour before the test. The Rehberg technique has been so widely employed in physiological and clinical studies that it has become universally known as simply the "creatinine" rather than the "exogenous creatinine" clearance.

Recently it has been demonstrated that, in the dog, this exogenous clearance is equivalent to the inulin clearance $(8,9)$ and to the ferrocyanide clearance (10). These results make it highly probable that the exogenous creatinine clearance does truly measure the glomerular filtrate in the dog. However, in man, no two of these clearances are identical. Miller and Winkler (11) studied the excretion of ferrocyanide in man and

\footnotetext{
1 The terms "chromogenic substance," “Jaffe-reactive material," "apparent creatinine" are all synonymous and indicate the creatinine equivalent of the color produced by the interaction between alkaline picrate and blood filtrates.
}

observed a marked difference as compared with the dog. They concluded that a portion of the ferrocyanide is reabsorbed by the tubular cells of the human kidney. Previously, Shannon (12) demonstrated that the exogenous clearance of creatinine in man is always somewhat greater than the inulin clearance. From his results it seemed reasonable to assume that the tubules of the human kidney secrete a portion of the creatinine which appears in the urine. This secretory effect in Shannon's experiments was most marked during the periods in which the concentration of creatinine was increasing in the plasma.

This kind of secretion must be distinguished from the behavior of phenol red which is undoubtedly excreted to a considerable extent by tubular secretion $(13,14,15)$; phenol red, in contrast to creatinine, is secreted to the same degree either with a rising or falling plasma concentration.

The studies reported here originated in an attempt to test the validity of the hypothesis that the secretion of exogenous creatinine observed by Shannon might be a response by the human kidney to a special stimulus rather than a continuous physiological process. However, the investigation of the excretion of creatinine in the normal physiological environment requires the determination of the specific endogenous creatinine clearance. Before such a determination is possible the presence of creatinine in normal human plasma must be proven; and if its existence can be demonstrated, a specific sensitive method for the analysis of creatinine is a further prerequisite for clearance determination.

One of us therefore undertook an investigation of the nature of the Jaffe-reactive material in human blood by specific techniques. Special bacterial enzymes were developed to decompose creatinine $(16,17)$. Evidence was obtained with two 
distinct enzyme systems, each with a high degree of specificity toward creatinine as compared with other closely related Jaffe-reactive compounds. Additional evidence was obtained from a spectrophotometric study employing the newly introduced and quite specific color reaction between creatinine and dinitrobenzoic acid. The results with these three separate systems were in such complete agreement that Miller and Dubos (18) concluded that creatinine exists in blood and comprises the major portion of the chromogenic material in normal plasma.

The enzymes may also be employed for the specific determination of creatinine (19). We have used this specific method for the determination of the endogenous creatinine in serum and urine. With this method it has been possible for the first time to obtain true endogenous creatinine clearances.

In this study, clearances of endogenous and exogenous creatinine (and urea in some cases) have been obtained in normal human subjects and in several patients with reduced renal function. It is assumed that inulin clearance measures the glomerular filtration rate in the human kidney. By a comparison of the creatinine clearance with the inulin clearance it appears possible to estimate the relative importance of filtration and secretion in the excretion of endogenous and exogenous creatinine.

\section{ANALYTICAL METHODS}

Fresh urine specimens and blood serum were employed for all the analyses.

Endogenous creatinine. The essential operations involved in the determination of the endogenous creatinine are (1) estimation of the creatinine equivalent of the total Jaffe-reactive material in the serum filtrate or urine, (2) decomposition of the creatinine by a specific enzyme and determination of the creatinine equivalent of the residual chromogenic substance, (3) calculation of the true creatinine as the difference between (1) and (2). The details of this method for the analysis of endogenous creatinine in serum and urine are described by Miller and Dubos (19).

Serum. A 1:5 filtrate of the serum was prepared using 1 volume of serum, 3 volumes $\mathrm{H}_{2} \mathrm{O}$ and 0.5 volume each of 10 per cent sodium tungstate and $2 / 3$ normal $\mathrm{H}_{2} \mathrm{SO}_{4}$. The suspension was centrifuged and filtered through good quality paper.

Urine. The urine samples were diluted to contain about $0.002 \mathrm{mgm}$. creatinine per cc.

The true creatinine was obtained in the filtrates and diluted urines by the technique described by Miller and
Dubos (19). The accuracy of the method is about 5 per cent in serum and probably slightly better in urine.

In their method, the final values for the creatinine equivalents are obtained from a calibration chart prepared from analyses on pure creatinine solutions. To minimize errors in calculation of the ratio of urine and serum concentrations, the analyses of creatinine in the urines and serum filtrates were performed at nearly the same concentration. The readings were always made in the range of maximum accuracy of the stufenphotometer. Furthermore, the analyses on comparable serum filtrates and urines were determined at approximately the same time to eliminate errors from variations of room temperature or changes in the reagents.

Exogenous creatinine. To make the accuracy of the determination of the exogenous creatinine comparable with that for the endogenous values, the same technique was employed for both. The more concentrated urines and $1: 5$ tungstic acid filtrates of serum were diluated to give about $0.002 \mathrm{mgm}$. of creatinine per cc. The concentrations were obtained in the same way before and after incubation with the enzyme. In almost every case it was found that the non-creatinine chromogenic material remaining after the incubation with the enzyme constituted a negligible fraction of the total.

Inulin. Inulin was determined as the difference between total reducing substance before and after acid hydrolysis. Tungstic acid filtrates of serum and suitably diluted urines were employed for analyses. The reducing sugars were estimated by the method of Shaffer and Somogyi (20). In some instances the glucose in serum filtrates was removed before hydrolysis by the use of yeast, while in others it was not.

Satisfactory results were obtained on known solutions of inulin by either technique. The method was accurate to about 5 per cent.

Urea. The blood filtrates and urines were analyzed by the hypobromite method of Van Slyke (21). The empirical correction for non-urea, nitrogen-producing compounds of whole blood was omitted; excellent agreement was found between the values thus obtained and comparative analyses with the more precise urease method (22).

\section{Calculation and definition of the various clearances}

The clearances for a given substance were calculated by dividing the urinary excretion rate by the mean concentration of the serum during the period. These values without changes for surface area are given in the text. The technique used to obtain the midpoint serum concentrations was the same as given by Winkler and Parra. (23).

By endogenous creatinine clearance is meant the value obtained from the specific analyses for endogenous creatinine in serum and urine. It should therefore be distinguished from the occasional values heretofore recorded in the literature for nonspecific "endogenous creatinine" or "apparent creatinine" clearances. The exogenous creatinine, inulin and urea clearances have their usual connotation. 
Accuracy of clearances. In view of the limits of technical accuracy of the methods for creatinine and for inulin, the calculated clearances of these substances are probably not accurate to better than about 10 per cent. Determinations of urea clearance are somewhat more accurate.

\section{PLAN OF EXPERIMENTS}

The experiments were planned so that in almost all of them the clearances of both endogenous and exogenous creatinine were obtained and compared with the simultaneously determined clearance of inulin. Clearances of urea were determined in many instances.

Continuous infusions of inulin and creatinine were given in most of the experiments with normal subjects. This procedure simplified clearance calculations by maintaining the concentration of these substances in the plasma fairly constant. The course of a typical experiment on a normal subject is presented graphically in Figure 1. In the morning the fasting subject was catheterized, his bladder washed out with saline, and

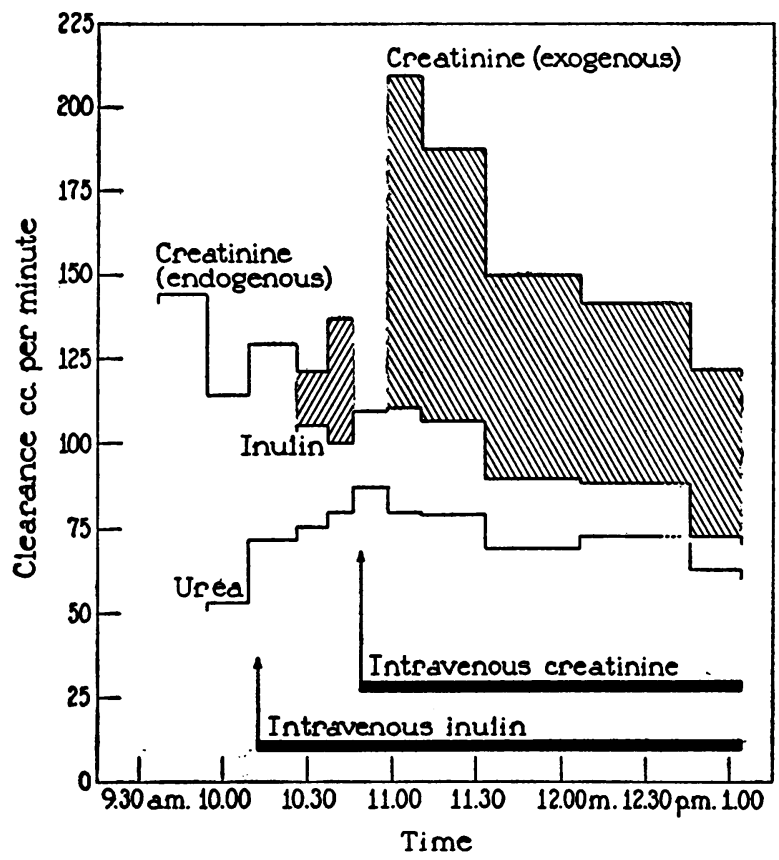

Fig. 1. An Experiment on a Normal Subject

Creatinine clearances were obtained at endogenous plasma levels and also after the intravenous injection of creatinine. These clearances are compared with inulin and urea clearances.

urine collections started. Forcing of fluids by mouth was also begun at this time. During the next three and one-half hours eleven successive specimens of urine were collected, the duration of each period varying from 10 to 40 minutes.
At appropriate times blood specimens were taken by venipuncture. During the third period the inulin infusion was started and continued throughout the remainder of the experiment. During the sixth period creatinine infusion was begun. Endogenous creatinine clearance was determined for the first five periods, during the last two of which it was compared with simultaneous inulin clearances. Exogenous creatinine and inulin clearances were obtained in the last five periods. The exact time relations of the various clearances are shown in Figure 1. The inulin was administered as follows: $100 \mathrm{cc}$. of 15 per cent inulin in normal saline were given rapidly; the infusion flask was then filled with a 5 per cent solution of inulin in normal saline and the rate of infusion reduced to about $4 \mathrm{cc}$. per minute. Such an arrangement resulted in a very constant level of inulin in the serum throughout the latter part of the experiment. Creatinine was first administered by the injection of 2.5 grams rapidly into an arm vein; then 2.5 grams of creatinine were added to the infusion flask containing the dilute inulin solution. This likewise gave a fairly constant concentration of creatinine in the serum of about 10 to $20 \mathrm{mgm}$. per cent.

Urea clearances were obtained by analysis of blood and urine for endogenous urea.

In all the experiments with nephritic subjects and in two with normal individuals, a variation of the technique just described was adopted. No attempt was made to maintain continuous infusions of inulin or of creatinine. Single large intravenous doses of these substances were given rapidly, after which the level of concentration in the serum was allowed to decline. The clearances were then calculated using interpolated values for serum concentrations according to a general method previously described (23). The course of a typical experiment of this type with a subject whose clearances were reduced to 15 per cent of normal is outlined in Figure 2.

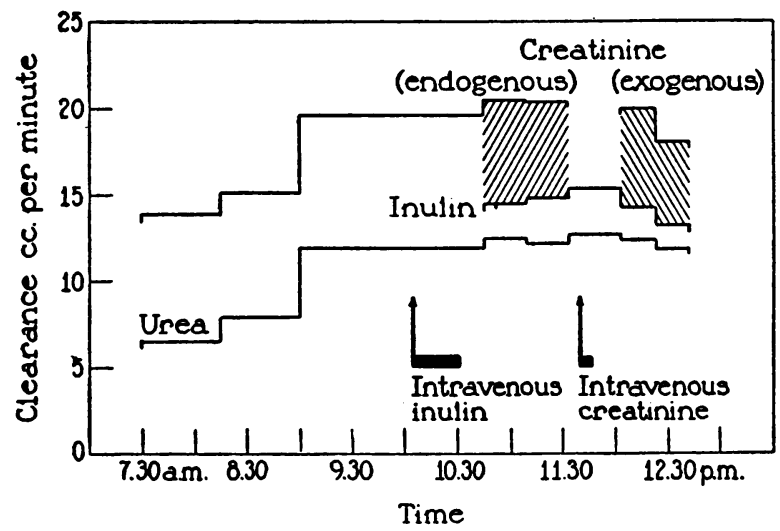

Fig. 2. An Experiment on a Patient with Marked Reduction of Renal Function

Endogenous and exogenous creatinine clearances are compared with simultaneously determined inulin and urea clearances. 
TABLE I

Subjects without renal disease.

Comparison of endogenous and exogenous creatinine clearances*

\begin{tabular}{|c|c|c|c|c|c|c|c|c|c|}
\hline \multirow{2}{*}{$\begin{array}{l}\text { Experi- } \\
\text { ment } \\
\text { number }\end{array}$} & \multirow{2}{*}{ Diagnosis } & \multirow{2}{*}{ Period } & \multicolumn{4}{|c|}{ Clearances } & \multicolumn{2}{|c|}{ Clearance ratio } & \multirow{2}{*}{$\frac{\text { Clearance ratio }}{\mathrm{C}_{\text {ex. }} / \mathrm{C}_{\text {end. }}}$} \\
\hline & & & $\mathrm{C}_{\text {end. }}$ & $\mathrm{C}_{\text {ex. }}$ & I & $\mathrm{U}$ & $\mathrm{C}_{\text {end./I }}$ & $\mathrm{C}_{\mathrm{ex} . / \mathbf{I}}$ & \\
\hline \multirow[t]{3}{*}{ I } & \multirow[t]{3}{*}{$\begin{array}{l}\text { Normal } \\
\text { M. } 48 \text { years } \\
\text { S.A. = } 1.68 \text { sq. m. } \\
\text { December } 15,1936\end{array}$} & \multirow[t]{3}{*}{$\begin{array}{l}1 \\
2 \\
3 \\
4 \\
5\end{array}$} & $\begin{array}{c}c c . \text { per } \\
\text { minute } \\
95 \\
84 \\
65 \\
99 \\
46\end{array}$ & $\begin{array}{l}c c \text {. per } \\
\text { minute }\end{array}$ & $\begin{array}{c}c c . \text { per } \\
\text { minute } \\
\\
101 \\
55\end{array}$ & $\begin{array}{c}c c . \text { per } \\
\text { minute } \\
51 \\
67 \\
43 \\
61 \\
26\end{array}$ & $\begin{array}{l}1.0 \\
0.8\end{array}$ & & \\
\hline & & & \multicolumn{6}{|c|}{ Creatinine intravenously } & \\
\hline & & & & $\begin{array}{l}140 \\
180\end{array}$ & $\begin{array}{r}97 \\
106 \\
115\end{array}$ & 58 & & $\begin{array}{l}1.3 \\
1.6\end{array}$ & 3.0 \\
\hline \multirow[t]{3}{*}{ II } & \multirow[t]{3}{*}{$\begin{array}{l}\text { Idem. } \\
\text { December 28, } 1936\end{array}$} & \multirow[t]{3}{*}{$\begin{array}{l}1 \\
2 \\
3 \\
4 \\
5\end{array}$} & $\begin{array}{l}144 \\
114 \\
129 \\
122 \\
137\end{array}$ & & $\begin{array}{l}106 \\
101\end{array}$ & $\begin{array}{l}53 \\
72 \\
76 \\
80\end{array}$ & $\begin{array}{l}1.2 \\
1.4\end{array}$ & & \\
\hline & & & \multicolumn{6}{|c|}{ Creatinine intravenously } & \\
\hline & & & & $\begin{array}{l}209 \\
188 \\
150 \\
142 \\
123\end{array}$ & $\begin{array}{r}109 \\
110 \\
107 \\
89 \\
88 \\
73\end{array}$ & $\begin{array}{l}87 \\
79 \\
78 \\
69 \\
73 \\
63\end{array}$ & & $\begin{array}{l}1.9 \\
1.8 \\
1.7 \\
1.6 \\
1.7\end{array}$ & 1.5 \\
\hline \multirow[t]{3}{*}{ III } & \multirow[t]{3}{*}{$\begin{array}{l}\text { Normal } \\
\text { M. } 36 \text { years } \\
\text { S.A. = } 1.51 \text { sq. m. }\end{array}$} & \multirow[t]{3}{*}{$\begin{array}{l}1 \\
2 \\
3 \\
4 \\
5 \\
6 \\
7\end{array}$} & $\begin{array}{r}120 \\
87 \\
111 \\
105 \\
91 \\
98 \\
118\end{array}$ & & $\begin{array}{r}88 \\
91 \\
118\end{array}$ & & $\begin{array}{l}1.0 \\
1.1 \\
1.0\end{array}$ & & \\
\hline & & & \multicolumn{6}{|c|}{ Creatinine intravenously } & \\
\hline & & & & $\begin{array}{l}178 \\
162 \\
147\end{array}$ & $\begin{array}{r}103 \\
90 \\
89 \\
89\end{array}$ & & & $\begin{array}{l}2.0 \\
1.8 \\
1.7\end{array}$ & 1.5 \\
\hline \multirow[t]{3}{*}{ IV } & \multirow[t]{3}{*}{$\begin{array}{l}\text { Normal } \\
\text { M. } 54 \text { years } \\
\text { S.A. }=1.62 \text { sq. m. }\end{array}$} & \multirow[t]{3}{*}{$\begin{array}{l}1 \\
2 \\
3\end{array}$} & $\begin{array}{l}116 \\
113 \\
127\end{array}$ & & 131 & 63 & 1.0 & & \\
\hline & & & \multicolumn{6}{|c|}{ Creatinine intravenously } & \\
\hline & & & & 158 & $\begin{array}{l}100 \\
145\end{array}$ & $\begin{array}{l}68 \\
57\end{array}$ & & 1.1 & 1.2 \\
\hline V & $\begin{array}{l}\text { Diabetes mellitus } \\
\text { M. } 25 \text { years } \\
\text { S.A. }=1.72 \text { sq. } \mathrm{m} .\end{array}$ & $\begin{array}{l}1 \\
2 \\
3 \\
4\end{array}$ & $\begin{array}{l}125 \\
166\end{array}$ & 210 & $\begin{array}{l}175 \\
157 \\
133\end{array}$ & $\begin{array}{l}64 \\
89 \\
63 \\
65\end{array}$ & 1.0 & 1.6 & 1.3 \\
\hline
\end{tabular}

* $\mathrm{C}=$ creatinine; $\mathrm{I}=$ inulin; $\mathrm{U}=$ urea. $\mathrm{C}_{\mathrm{end}}$. and $\mathrm{C}_{\mathrm{ex}}$. stand for endogenous and exogenous creatinine clearances. The clearance ratio $C_{e n d} . / C_{e x}$. is calculated as the quotient of the first exogenous creatinine clearance and the last endogenous creatinine clearance in each experiment. 
Throughout the course of all the experiments an active diuresis was maintained so that the urine flow was almost always greater than $5 \mathrm{cc}$. per minute. In each experiment from 3 to 5 grams of creatinine and from 20 to 40 grams of inulin were administered. The exact amount was adjusted so that the concentration of creatinine in the serum lay between 10 and $15 \mathrm{mgm}$. per cent and that of inulin between 100 and $150 \mathrm{mgm}$. per cent during the greater part of the course. Urea clearances were obtained without injection of urea.

Most of the normal subjects were catheterized. Because of the marked diuresis washing of the bladder at the end of each period was omitted. The nephritic patients were not catheterized, but all subjects were coöperative and without evidence of faulty bladder evacuation. Accurate collections were possible in each experiment.

\section{RESULTS}

Tables I and II present a summary of the data on clearances obtained from eight experiments on seven subjects who had no evidence of renal disease. In the five experiments of Table I the exogenous and endogenous creatinine clearances were determined. The three experiments grouped in Table II include determinations of endogenous, but not of exogenous creatinine clearances.

In five of the eight experiments the endogenous creatinine clearance has about the same magnitude as the inulin clearance, while in the remaining three it is somewhat higher. In two experiments with the same subject (Table I, Experiments I and II) the endogenous creatinine clearance was in the first instance nearly equal to the inulin clearance and in the second somewhat higher.

Immediately after the injection of creatinine, the creatinine clearance characteristically rose abruptly 50 per cent or more above its endogenous level, while the simultaneous inulin and urea clearances did not change. This is reflected in a sharp rise in the creatinine: inulin ratio, and in the high ratio of exogenous to endogenous clearance of creatinine. Of the five experiments of Table I, only one (Experiment IV) failed to show this effect.

In Tables III and IV are presented the data from six experiments on four subjects with renal disease. Their renal function varied from 15 to 100 per cent of normal. The results differ from those found in the normal subjects in two respects: (1) the endogenous creatinine clearance is regularly higher than the simultaneous inulin clearance, (2) the exogenous clearance is usually nearly identical with the endogenous clearance of creatinine. In other words, the abrupt increase of creatinine clearance following the injection of creatinine in normal subjects fails to appear in these experiments. Perhaps a slight "normal" effect may have occurred in the second experiment of Table III.

The only marked exceptions appear in Experiments II and III of Table IV. These experiments are unusual in that in Experiment $I$ with

TABLE II

Normal subjects

(Endogenous creatinine clearances only.)

\begin{tabular}{|c|c|c|c|c|c|c|}
\hline \multirow{2}{*}{$\begin{array}{c}\text { Experi- } \\
\text { ment } \\
\text { number }\end{array}$} & \multirow{2}{*}{ Diagnosis } & \multirow{2}{*}{ Period } & \multicolumn{3}{|c|}{ Clearances } & \multirow{2}{*}{$\frac{\text { Clearance ratio }}{\mathrm{C}_{\text {end./I }}}$} \\
\hline & & & $\mathrm{C}_{\text {end. }}$ & I & U & \\
\hline I & $\begin{array}{l}\text { Normal }(\mathrm{S}) \\
\text { M. } 46 \text { years } \\
\text { S.A. }=1.67 \text { sq. m. }\end{array}$ & $\begin{array}{l}1 \\
2 \\
3\end{array}$ & $\begin{array}{c}\text { cc. per } \\
\text { minute } \\
299 \\
144 \\
172\end{array}$ & $\begin{array}{c}c c . \text { per } \\
\text { minute } \\
212 \\
115\end{array}$ & $\begin{array}{l}c c \text {. per } \\
\text { minute }\end{array}$ & $\begin{array}{l}1.4 \\
1.3\end{array}$ \\
\hline II & $\begin{array}{l}\text { Normal }(\mathrm{R}) \\
\text { M. } 41 \text { years } \\
\text { S.A. }=1.67 \text { sq. m. }\end{array}$ & $\begin{array}{l}1 \\
2 \\
3 \\
4\end{array}$ & $\begin{array}{r}127 \\
84 \\
192 \\
151\end{array}$ & $\begin{array}{l}145 \\
100\end{array}$ & & $\begin{array}{l}1.3 \\
1.5\end{array}$ \\
\hline III & $\begin{array}{l}\text { Normal }(C) \\
\text { M. } 36 \text { years } \\
\text { S.A. }=1.42 \text { sq. m. }\end{array}$ & $\begin{array}{l}1 \\
2 \\
3 \\
4 \\
5\end{array}$ & $\begin{array}{r}75 \\
107 \\
59 \\
106 \\
75\end{array}$ & $\begin{array}{l}99 \\
82\end{array}$ & $\begin{array}{l}33 \\
38 \\
41 \\
55 \\
47\end{array}$ & $\begin{array}{l}1.1 \\
0.9\end{array}$ \\
\hline
\end{tabular}

$\mathrm{C}_{\text {end. }}=$ endogenous creatinine; $\mathrm{I}=$ inulin; $\mathrm{U}=$ urea. 
the same patient at an earlier date there was no response to added creatinine. The subject of the three experiments given in Table IV was a patient with mild nephritis who at the time of the first experiment in March had been for many years previously on a low protein diet. The clearances in this first experiment (especially for urea) are clearly depressed below normal levels. The patient was then placed on a much higher protein intake for some weeks. The clearances as determined in Experiment II in May and in Experiment III in June rose to the normal range, and the normal type of response to creatinine injection appeared. In the last experiment the behavior is indistinguishable from that of the normal subjects.

\section{DISCUSSION}

Since in many of the experiments with normal subjects the endogenous creatinine clearance is identical with the inulin clearance, it appears likely that under normal circumstances the endogenous creatinine clearance may approximate the glomerular filtration rate in the human kidney. The

TABLE III

Subjects with diminished renal function.

Comparison of endogenous and exogenous creatinine clearances *

\begin{tabular}{|c|c|c|c|c|c|c|c|c|c|}
\hline \multirow{2}{*}{$\begin{array}{c}\text { Experi- } \\
\text { ment } \\
\text { number }\end{array}$} & \multirow{2}{*}{ Diagnosis } & \multirow{2}{*}{ Period } & \multicolumn{4}{|c|}{ Clearances } & \multicolumn{2}{|c|}{ Clearance ratio } & \multirow{2}{*}{$\frac{\text { Clearance ratio }}{\mathrm{C}_{\text {ex } .} / \mathrm{C}_{\text {end. }}}$} \\
\hline & & & $\mathrm{C}_{\text {end. }}$ & $\mathrm{C}_{\text {ex. }}$ & $\mathbf{I}$ & $\mathrm{U}$ & $\mathrm{C}_{\text {end./I }}$ & $\mathrm{C}_{\text {ex } / \mathbf{I}}$ & \\
\hline \multirow[t]{3}{*}{$\dot{I}$} & \multirow[t]{3}{*}{$\begin{array}{l}\text { Hypertension } \\
\text { ? nephrosclerosis } \\
\text { M. } 54 \text { years } \\
\text { S.A. }=1.70 \text { sq. m. }\end{array}$} & \multirow[t]{3}{*}{$\begin{array}{l}1 \\
2 \\
3 \\
4\end{array}$} & $\begin{array}{l}c c \text { per } \\
\text { minute } \\
108 \\
114 \\
119 \\
108\end{array}$ & $\begin{array}{l}c c \text { per } \\
\text { minute }\end{array}$ & $\begin{array}{l}c c . \text { per } \\
\text { minute }\end{array}$ & $\begin{array}{l}\text { cc.per } \\
\text { minute } \\
\\
74 \dagger \\
55\end{array}$ & $\begin{array}{l}1.5 \\
1.2\end{array}$ & & \multirow[b]{3}{*}{1.1} \\
\hline & & & \multicolumn{6}{|c|}{ Creatinine intravenously } & \\
\hline & & & & $\begin{array}{r}115 \\
97\end{array}$ & $\begin{array}{r}82 \\
115 \\
81\end{array}$ & $\begin{array}{l}44 \\
84 \\
63\end{array}$ & & $\begin{array}{l}1.0 \\
1.2\end{array}$ & \\
\hline \multirow[t]{3}{*}{ II } & \multirow[t]{3}{*}{$\begin{array}{l}\text { Chronic nephritis } \\
\text { M. } 19 \text { years } \\
\text { S.A. }=1.76 \text { sq. m. }\end{array}$} & \multirow[t]{3}{*}{$\begin{array}{l}1 \\
2 \\
3 \\
4 \\
5 \\
6\end{array}$} & $\begin{array}{r}69 \\
104 \\
93 \\
112 \\
117 \\
100\end{array}$ & & $\begin{array}{l}83 \\
65\end{array}$ & $\begin{array}{l}15 \\
22 \\
21 \\
33 \\
47 \\
35\end{array}$ & $\begin{array}{l}1.4 \\
1.5\end{array}$ & & \multirow[b]{3}{*}{1.2} \\
\hline & & & \multicolumn{6}{|c|}{ Creatinine intravenously } & \\
\hline & & & & $\begin{array}{l}117 \\
105\end{array}$ & $\begin{array}{l}63 \\
62 \\
60\end{array}$ & $\begin{array}{l}38 \\
43 \\
45\end{array}$ & & $\begin{array}{l}1.9 \\
1.8\end{array}$ & \\
\hline \multirow[t]{3}{*}{ III } & \multirow[t]{3}{*}{$\begin{array}{l}\text { Chronic nephritis } \\
\text { (S) M. } 24 \text { years } \\
\text { S.A. }=1.67 \text { sq. } \mathrm{m} .\end{array}$} & \multirow[t]{3}{*}{$\begin{array}{l}1 \\
2 \\
3 \\
4 \\
5\end{array}$} & $\begin{array}{l}13.9 \\
15.1 \\
19.6 \\
20.4 \\
20.4\end{array}$ & & $\begin{array}{l}14.4 \\
14.7\end{array}$ & $\begin{array}{r}6.6 \\
7.9 \\
11.9 \\
12.4 \\
12.3\end{array}$ & $\begin{array}{l}1.4 \\
1.4\end{array}$ & & \\
\hline & & & \multicolumn{6}{|c|}{ Creatinine intravenously } & \\
\hline & & & & $\begin{array}{l}20.0 \\
18.0\end{array}$ & $\begin{array}{l}15.4 \\
15.6 \\
13.1\end{array}$ & $\begin{array}{l}12.7 \\
12.4 \\
11.9\end{array}$ & & $\begin{array}{l}1.3 \\
1.5\end{array}$ & 1.0 \\
\hline
\end{tabular}

* For Legend-see Table I.

t Calculated from the excretion for part only of the period. 
TABLE IV

Repeated determinations of endogenous and exogenous creatinine clearances in a single subject with latent nephritis, during a period of clinical improvement *

\begin{tabular}{|c|c|c|c|c|c|c|c|c|c|}
\hline \multirow{2}{*}{$\begin{array}{c}\text { Experi- } \\
\text { ment } \\
\text { number }\end{array}$} & \multirow{2}{*}{ Diagnosis } & \multirow{2}{*}{ Period } & \multicolumn{4}{|c|}{ Clearances } & \multicolumn{2}{|c|}{ Clearance ratio } & \multirow{2}{*}{$\frac{\text { Clearance ratio }}{\mathrm{C}_{\text {ex./Cend. }}}$} \\
\hline & & & $\mathrm{C}_{\text {end. }}$ & $c_{\text {ex. }}$ & $\mathbf{I}$ & U & $\mathrm{C}_{\text {end./I }}$ & $\mathrm{C}_{\text {ex./I }}$ & \\
\hline \multirow[t]{3}{*}{ I } & \multirow[t]{3}{*}{$\begin{array}{l}\text { Chronic nephritis } \\
\text { March } 22,1937 \\
\text { M. } 13 \text { years } \\
\text { S.A. = } 1.47 \text { sq. m. }\end{array}$} & \multirow[t]{3}{*}{$\begin{array}{l}1 \\
2 \\
3 \\
4 \\
5\end{array}$} & $\begin{array}{c}c c \text { per } \\
\text { minute } \\
67 \\
41 \\
108 \\
106 \\
100\end{array}$ & $\begin{array}{c}c c \text { per } \\
\text { minute }\end{array}$ & $\begin{array}{c}c c \text { per } \\
\text { minute } \\
\\
61 \\
58\end{array}$ & $\begin{array}{c}c c \text { per } \\
\text { minute } \\
11 \\
4.2 \\
22 \\
36 \\
35\end{array}$ & $\begin{array}{l}1.7 \\
1.7\end{array}$ & \multirow[b]{3}{*}{$\begin{array}{l}1.4 \\
1.2\end{array}$} & \multirow[b]{3}{*}{1.1} \\
\hline & & & \multicolumn{5}{|c|}{ Creatinine intravenously } & & \\
\hline & & & & $\begin{array}{r}110 \\
96\end{array}$ & $\begin{array}{l}74 \\
79 \\
80\end{array}$ & $\begin{array}{l}37 \\
32 \\
29\end{array}$ & & & \\
\hline \multirow[t]{3}{*}{ II } & \multirow[t]{3}{*}{$\begin{array}{l}\text { Idem. } \\
\text { May } 12,1937\end{array}$} & \multirow[b]{3}{*}{$\begin{array}{l}3 \\
4 \\
5\end{array}$} & $\begin{array}{r}79 \\
100\end{array}$ & & & $\begin{array}{l}27 \\
28\end{array}$ & & & \multirow[b]{3}{*}{1.7} \\
\hline & & & \multicolumn{5}{|c|}{ Creatinine intravenously } & & \\
\hline & & & & $\begin{array}{l}170 \\
143\end{array}$ & & $\begin{array}{l}46 \\
51 \\
52\end{array}$ & & & \\
\hline \multirow[t]{3}{*}{ III } & \multirow[t]{3}{*}{$\begin{array}{l}\text { Idem. } \\
\text { June 1, } 1937\end{array}$} & \multirow[t]{3}{*}{$\begin{array}{l}1 \\
2 \\
3 \\
4\end{array}$} & $\begin{array}{r}130 \\
98 \\
93 \\
99\end{array}$ & & $\begin{array}{r}102 \\
88\end{array}$ & $\begin{array}{l}26 \\
42 \\
64 \\
56\end{array}$ & $\begin{array}{l}0.9 \\
1.1\end{array}$ & & \\
\hline & & & \multicolumn{5}{|c|}{ Creatinine intravenously } & & \\
\hline & & & & $\begin{array}{l}159 \\
134\end{array}$ & $\begin{array}{l}70 \\
75 \\
82\end{array}$ & $\begin{array}{l}57 \\
54 \\
49\end{array}$ & & $\begin{array}{l}2.1 \\
1.6\end{array}$ & 1.6 \\
\hline
\end{tabular}

* For Legend see Table I.

reasons for believing that inulin clearance in man measures the true filtration rate have been stated by Shannon and Smith (24). This contention would be much strengthened if other clearances in man were found to have the same numerical value. As mentioned in the earlier part of this paper such consistent identity of three clearances has been demonstrated in the dog. No two consistently identical clearances in man have yet been found. There are many instances in our experiments in which endogenous creatinine and inulin clearance clearly differ. However, the fact that they are almost identical in many periods must be considered added evidence that this common value is the true filtration rate. Other explanations of this identity are of course possible, as for example an approximate balance between secretion and reabsorption of endogenous creatinine, so that the solution of the problem must await the discovery of substances which are more consistently identical.

In the experiments with normal subjects the administration of creatinine resulted in a marked increase in the clearance of creatinine, without parallel changes in the clearances of inulin or urea. This naturally leads to the conclusion that the exogenous creatinine is only partly excreted by filtration, the remainder being excreted by some other means. This conclusion is consistent with that already reached by Shannon (12) and by Winkler and Parra (23) from other studies of the exogenous creatinine clearance in man. 
Tubular secretion has been advanced by Shannon as a hypothesis to explain this added creatinine excretion. If this hypothesis be accepted, our experiments indicate that such secretion may or may not be present in normal individuals, but that it is readily evoked by the administration of creatinine.

The number of nephritic subjects studied is too small to venture any general conclusions about creatinine secretion in nephritis. Evidently, with severe reduction of filtration rate the secretory mechanism is not necessarily abolished. In the one case of this type studied (Figure 2), the secretory mechanism seemed active both before and after administration of exogenous creatinine. The subjects with lesser degrees of impairment of clearances behaved irregularly, sometimes like the normal subjects, often like the severe nephritic.

The repeated determinations of clearances of the patient with latent nephritis at different times during his clinical course (Table IV) illustrate the important fact that the normal response to injected creatinine may be absent at one time and present at another. The correlation between the appearance of normal behavior of the creatinine clearances and the rise of the filtration rate to normal may possibly explain this varying behavior. The general impression from our limited observations on nephritic subjects suggests that it is chiefly the lability, rather than the existence, of the secretory mechanism which tends to be abolished with renal impairment. More observations, however, are needed before this can be stated as a general proposition.

The nature of the secretory mechanism is further analyzed in Table V. This table presents certain calculations made on the assumption that inulin clearance measures glomerular filtration, and that the difference between creatinine and inulin clearance is due to tubular secretion of creatinine. The experiments used as a basis are those whose course has previously been illustrated by Figures 1 and 2 . In the normal subject, following the injection of creatinine, the amount of creatinine excreted per unit time by filtration increased more than tenfold, and that excreted by secretion some thirtyfold. In the nephritic subject a similar but less marked increase in the amounts excreted by both mechanisms is observed. Evidently, the absolute rate of secretion of creatinine by the tubular cells is not fixed. The constant ratio of both the endogenous and exogenous creatinine clearances to the inulin clearance in the nephritic subject suggests, at first sight, fixation of filtration and secretory activity. However, an analysis such as that presented. in Table $\mathrm{V}$ demonstrates that it is simply the partition between the two routes which is fixed, not the amounts secreted or the amounts filtered in a given interval. With filtration there is an adequate mechanical explanation of the fact that the rate of filtration of a substance is not constant but dependent on the serum concentration (see discussion by Rehberg (7) and Van Slyke, Rhoads, Hiller and Alving (25).

TABLE V

Comparative rates of filtration and secretion of creatinine *

\begin{tabular}{|c|c|c|c|c|c|c|c|}
\hline & \multicolumn{2}{|c|}{ Clearances } & \multirow{2}{*}{$\begin{array}{l}\text { Total excretion } \\
\text { rate of creatinine } \\
\text { F. }+S \text {. }\end{array}$} & \multirow{2}{*}{$\begin{array}{l}\text { Excretion of } \\
\text { creatinine } \\
\text { by F. }\end{array}$} & \multirow{2}{*}{$\begin{array}{l}\text { Per cent } \\
\text { of total } \\
\text { by F. }\end{array}$} & \multirow{2}{*}{$\begin{array}{l}\text { Excretion of } \\
\text { creatinine } \\
\text { by S. }\end{array}$} & \multirow{2}{*}{$\begin{array}{l}\text { Per cent } \\
\text { of total } \\
\text { by } \mathrm{S} .\end{array}$} \\
\hline & $\mathrm{c}$ & I & & & & & \\
\hline $\begin{array}{l}\text { (A) Normal subject } \\
\text { (Table I, Experiment II) } \\
\text { Last endogenous } \\
\text { First exogenous }\end{array}$ & $\begin{array}{l}137 \\
209\end{array}$ & $\begin{array}{l}101 \\
110\end{array}$ & $\begin{array}{c}\text { mgm. per minute } \\
\\
1.25 \\
22.80\end{array}$ & \begin{tabular}{c|} 
mgm. per minute \\
\\
0.92 \\
11.97
\end{tabular} & $\begin{array}{l}\text { per cent } \\
\\
74 \\
53\end{array}$ & $\begin{array}{c}\text { mgm. per minute } \\
\\
0.33 \\
10.83\end{array}$ & $\begin{array}{l}\text { per cent } \\
26 \\
47\end{array}$ \\
\hline $\begin{array}{l}\text { (B) Nephritic subject } \\
\text { (Table III, Experiment III) } \\
\text { Last endogenous } \\
\text { First exogenous }\end{array}$ & $\begin{array}{l}20.4 \\
20.0\end{array}$ & $\begin{array}{l}14.7 \\
14.3\end{array}$ & $\begin{array}{l}1.29 \\
4.14\end{array}$ & $\begin{array}{l}0.93 \\
2.95\end{array}$ & $\begin{array}{l}72 \\
71\end{array}$ & $\begin{array}{l}0.36 \\
1.19\end{array}$ & $\begin{array}{l}28 \\
29\end{array}$ \\
\hline
\end{tabular}

* F. refers to "glomerular filtration." S. refers to "tubular secretion." 
However, with secretion there is no such evident reason why cellular secretory activity should vary so widely. Constancy of creatinine clearance cannot possibly mean constancy of secretory rate unless serum concentration is at the same time constant. In our experiments and in those of others, there are many instances in which the exogenous creatinine clearance continues to be greater than the inulin clearance by some approximately constant percentage. Since in these experiments the creatinine concentration in the serum is usually either rising or falling, this means not constancy of secretory rate but linear variation of secretory rate with serum concentration. Evidently this phenomenon which we call "secretion" for want of a better name is a very special mechanism, and may possibly be related in some way to filtration.

\section{CONCLUSIONS}

1. The renal excretion of endogenous creatinine in normal subjects is usually but not invariably equal to the inulin clearance.

2. The exogeneous creatinine clearance in normal subjects immediately following the injection of creatinine rises abruptly to a much higher value than the endogenous creatinine clearance.

3. This increase in the exogenous over the endogenous excretion of creatinine is not associated with any change in filtration rate, as measured by the inulin clearance.

4. The endogenous creatinine clearance in subjects with depressed renal function is usually higher than the inulin clearance.

5. The exogenous clearance in these subjects does not regularly rise above the endogenous creatinine clearance after the injection of creatinine.

6. These experiments support the hypothesis that exogenous creatinine is excreted both by filtration and secretion, while endogenous creatinine under normal physiological conditions is excreted almost wholly by filtration alone.

7. The amount of creatinine secreted by the human renal tubules, estimated by the difference between the clearances of creatinine and inulin, varies within wide limits.

\section{BIBLIOGRAPHY}

1. Behre, J. A., and Benedict, S. R., Studies in creatine and creatinine metabolism. IV. On the question of the occurrence of creatinine and creatine in blood. J. Biol. Chem., 1922, 52, 11.

2. Gaebler, O. H., Further studies of blood creatinine. J. Biol. Chem., 1930, 89, 451.

3. Bohn, H., and Hahn, F., Untersuchungen zum Mechanismus des blassen Hochdrucks. Utber das wahre und falsche Kreatin und Kreatinin des Blutes. Die Erniedrigung des Blutkreatinspiegels beim blassen Hochdruck. Ztschr. f. klin. Med., 1933, 125, 458.

4. Ferro-Luzzi, G., Utber das sogenannte "wahre Kreatinin" des Blutes. Biochem. Ztschr., 1935, $275,422$.

5. Hayman, J. M., Jr., Johnston, S. M., and Bender, J. A., On the presence of creatinine in blood. J. Biol. Chem., 1935, 108, 675.

6. Danielson, I. S., On the presence of creatinine in blood. J. Biol. Chem., 1936, 113, 181.

7. Rehberg, P. B., Studies on kidney function. I. The rate of filtration and reabsorption in the human kidney. Biochem. J., 1926, 20, 447.

8. Richards, A. N., Westfall, B. B., and Bott, P. A., Renal excretion of inulln, creatinine and xylose in normal dogs. Proc. Soc. Exper. Biol. and Med., 1934, 32, 73.

9. Shannon, J. A., The excretion of inulin by the dog. Am. J. Physiol., 1935, 112, 405.

10. Van Slyke, D. D., Hiller, A., and Miller, B. F., The clearance, extraction percentage and estimated filtration of sodium ferrocyanide in the mammalian kidney. Comparison with inulin, creatinine and urea. Am. J. Physiol., 1935, 113, 611.

11. Miller, B. F., and Winkler, A., The ferrocyanide clearance in man. J. Clin. Invest., 1936, 15, 489.

12. Shannon, J. A., The renal excretion of creatinine in man. J. Clin. Invest., 1935, 14, 403.

13. Marshall, E. K., Jr., and Vickers, J. L., The mechanism of the elimination of phenolsulphonephthalein by the kidney-a proof of secretion by the convoluted tubules. Bull. Johns Hopkins Hosp., 1923, 34, 1.

14. Marshall, E. K., Jr., The secretion of phenol red by the mammalian kidney. Am. J. Physiol., 1931, 99, 77.

15. Shannon, J. A., The excretion of phenol red by the dog. Am. J. Physiol., 1935, 113, 602.

16. Miller, B. F., and Dubos, R., Enzyme for decomposition of creatinine and its action on the "apparent creatinine" of blood. Proc. Soc. Exper. Biol. and Med., 1936, 35, 335.

17. Dubos, R., and Miller, B. F., The production of bacterial enzymes capable of decomposing creatinine. J. Biol. Chem., 1937, 121, 429.

18. Miller, B. F., and Dubos, R., Studies on the presence of creatinine in human blood. J. Biol. Chem., 1937, 121, 447.

19. Miller, B. F., and Dubos, R., Determination by a specific, enzymatic method of the creatinine content of blood and urine from normal and nephritic individuals. J. Biol. Chem., 1937, 121, 457. 
20. Shaffer, P. A., and Somogyi, M., Copper-iodometric reagents for sugar determination. J. Biol. Chem., 1933, 100, 695.

21. Van Slyke, D. D., The manometric determination of urea in blood and urine by the hypobromite reaction. J. Biol. Chem., 1929, 83, 449.

22. Van Slyke, D. D., Determination of urea by gasometric measurement of the carbon dioxide formed by the action of urease. J. Biol. Chem., 1927, 73, 695.

23. Winkler, A. W., and Parra, J., The measurement of glomerular filtration. Creatinine, sucrose, and urea clearances in subjects without renal disease. J. Clin. Invest., 1937, 16, 859.

24. Shannon, J. A., and Smith, H. W., The excretion of inulin, xylose and urea by normal and phlorizinized man. J. Clin. Invest., 1935, 14, 393.

25. Van Slyke, D. D., Rhoads, C. P., Hiller, A., and Alving, A. S., Relationships between urea excretion, renal blood flow, renal oxygen consumption, and diuresis. The mechanism of urea excretion. Am. J. Physiol., 1934, 109, 336. 